\title{
CORRELATES OF MANAGEMENT OF SCHOOL SECURITY OPERATIONS AND SCHOOL EFFECTIVENESS IN TERTIARY EDUCATIONAL INSTITUTIONS IN KEBBI STATE, NIGERIA; IMPLICATIONS FOR EDUCATIONAL MANAGERS
}

\author{
Dr. Sani Dantani MANGA \\ Department of Educational Foundations, UsmanuDanfodiyo University, Sokoto, Nigeria \\ Email: sanidmanga@gmail.com
}

\begin{abstract}
This study investigated the management of operations of Security Guards as a correlate of school effectiveness in tertiary educational institutions in Kebbi State. The study assessed the awareness of basic security operations and the quality of planning of security operations. The extent which these variables of awareness and planning of security are related to school effectiveness was determined. In conducting the study, 150 participants were deliberately selected to comprise 39 school managers and 111 security guards from three selected educational institutions. A descriptive survey design of the correlation type was adopted for the study. Self-designed and validated instrument with reliability index of .87 was used to collect data. Standard deviation, z-scores and Pearson correlation coefficient at 0.05 alpha kevel were used in analyzing the data. It was found that the level of awareness of roles by security guards and the quality of planning of security operations were rated low even though the two variables were significantly correlated to school effectiveness. It was therefore recommended that school managers should device enlightenments strategies such as regular training workshops as well as scientific planning of security operations to provide a more secured school environment to enhance school effectiveness in tertiary educational institutions in Kebbi State.
\end{abstract}

Doi: $10.31219 /$ osf.io/duvtx

(C) 2020 The Authors. Published by ISJ.

This is an open access article under the CC BY 4.0 license (https://creativecommons.org/licenses/by-nc-nd/4.0/) 


\section{Introduction}

In every nation of the world, the importance of education to economic growth and development is highly acknowledged. The rational belief in the efficacy of education as an indispensable instrument of national development has led many countries to devout their limited resources to the development of educational institutions at various levels (Alabi, 2011). In Nigeria government believes that tertiary educational institutions will champion the course of global peace and security needed for development. They have a responsibility to develop strategies that will enhance the level of security in campuses (Akkangbou, 2015). Thus, the provision of efficient security operations is a necessary strategy towards providing a secured and peaceful school environment that will enhance the realization of the fundamental goals of teaching, research, and community service (Abgu, Adamu \& Wamu, 2014).

The provision of efficient security operations largely depends on the employment of intelligent, courageous, loyal, patriotic, well trained and incorruptible Security Guards. In this paper, Security Guards are personnel who are and formally employed and paid to protect, assets and people in an organization. School security guards are uniformed school personnel who are vested with the responsibility to protect lives and property in a school environment (Suleiman, 2018). This implies that school security guards have a central role to play in maintaining the desired level of security in tertiary educational institutions for the attainment of schools effectiveness.

From the security perspective, this paper operationalizes school effectiveness as the creation and sustenance of a conducive school environment that is consistently alert to security threats and is capable of defending staff and protecting students from criminal activities. It is the ability of a school to maintain a peaceful environment for smooth running of academic and non-academic activities in tertiary educational institutions. Management of school security operations has to do with creation of awareness of security operations especially by school security guards as well as the planning of school security operations. This study investigated the extent to which security guards in tertiary educational institutions in Kebbi State are aware of basic security operations. It also examined the quality of planning of security operations in tertiary educational institution in Kebbi State. Therefore, in this study, the management of these security variables were taken into consideration as correlates of school effectiveness especially as it affects teaching research and community service in tertiary educational institutions in Kebbi State. In this regards, Adelugba, and Ujomo (2008) opined that the management of tertiary educational institutions have the duty of deriving strategies to attain the desired level of school effectiveness. 


\section{Statement of Problem}

Nigeria's transformation agenda can only be attained when quality education is provided to the citizens. Tertiary educational institutions are expected to champion the course of providing sound education for rapid socio-economic growth. But for schools to perform their academic functions effectively there must be adequate security. This means that effective security operations must be mapped out and meticulously executed to keep the schools safe. But one the major challenges of providing adequate security in schools seem to be the poor understanding of basic security operations to be performed by school security guards. This may not be unconnected with poor planning of security activities in various schools. Thus, the main thrust of this study is to investigate the level of awareness of security operations, quality of planning of security operations and how they correlate with school effectiveness in tertiary educational institution in Kebbi State.

\section{Objectives of the Study}

The primary objective of this study is to assess and explain the correlates of management of security operations and school effectiveness in tertiary educational institutions in Kebbi State.

The specific objectives were to:

1. To find out the level of awareness of types of security operations in tertiary educational institutions in Kebbi State.

2. To determine the quality of planning of school security operations in tertiary educational institutions in Kebbi State.

3. To ascertain the co-relation among awareness, planning of security operations and variables on school effectiveness in tertiary educational institutions in Kebbi State.

\section{Research Questions}

For the purpose of this study, the following research questions were raised:

1. What is level of awareness of types of security operations in tertiary educational institution in Kebbi State?

2. What is the quality of planning of security operations in tertiary educational institutions in Kebbi State?

3. Is there any co-relation among awareness, planning of security operations and variables on school effectiveness in tertiary institutions in Kebbi State? 


\section{Research Hypothesis}

As additional guide to for this study, the following null hypothesis was formulated.

Ho1: Awareness of security operations and quality of planning of security operations do not significantly co-relate with school effectiveness in tertiary educational institutions in Kebbi State.

\section{Review of Related Literature}

The degree of efficiency and effectiveness of performance of security operations depends largely on the extent to which security guards correctly perceive their duties and responsibilities. Ufane and Adunze (2015) however, noted that many security guards in tertiary educational institutions are not fully conscious of the scope of their duties and operational responsibilities. This according to Abolarin (2010) has resulted in the poor discharge of security operations across tertiary educational institutions in Nigeria. Security Guards in school premises have a number of roles to play in the excursion of their statutory duties, these roles were identified and highlighted in Suleiman (2010) to include: prevention of crimes, accidents, fire out-breaks and all forms of threats against the interest of the organization. It also includes patrolling of school premises, regulating parking and traffic control, access control and apprehension of criminals. Access control has to do with ensuring that only persons with legitimate business in the premises are allowed to enter in an orderly manner-after due checking, verification and identification. Identification involves checking and verifying person requesting entrance into the premises to confirm who they say they are, and who they wish to see before being given approval or clearance to proceed. Authorizing is the permission to pass through the gate or reception area into the premises or building after verification and approval from the person to be visited. Escorting or guiding the authorized visitors to the place of his/her visits to prevent him/her from wandering into in approval areas. A member of staff visited should escort the visitor to exist to complete exist formation. Documentation of entrants into schools gate and exist from premises Searching visitors: males searching males only and females searching females only.

Other duties were identified by Arisi (2011) to include Key control and issuance; dealing with lost and found items, querying of suspected goods and suspicious persons; reporting security breaches as appropriate; arresting: and use of handcuffs or restraints; performance of First Aid to victims; responding to emergencies in the case of missing persons, broken down vehicles on the roads, drawing or lock out in lifters; serve as body guards to principal officers; enforce safety rules and regulations; daters employee misconduct, and cooperate and link up with other security agencies in the community. Akosun (2013).

Apart from knowledge of security roles by Security Guards, another important aspect of security provision is the planning of security operations. Manga (2014) is of the view that planning of security 
operations is the first step towards effective performance of security duties by the security guards. Mclaren (2018) argued that the poor quality of security in schools is directly correlated with poor planning or lack of it. Suleiman (2018) outlined vital issues in planning of security operations in schools to include: establishing posts and patrols for security guard after careful education of existing security risks in the area; determining time requirements for posts and patrols giving consideration to the number of hours, per day, and number of days per week when that each post or patrol must be manned. This is to done taking into consideration operational hours of school facilities, peak hours of reduction and human traffic, periods when employees are not present in buildings or activity areas such as closing hours, weekends, and national holidays; planning for patrol logistics in terms of manpower, financial and material requirements for effective performance of security operations; preparation of guards instructions in terms of general, specific and temporary orders carefully worded to include all necessary phases of rains assignment, wearing of uniforms, reporting far duty, handing over and record keeping.

Preparation of guard manual is a complex intellectual operation done by experts in other to develop a security handbook covering standing operating procedures, setting and polices, organization, authority and other requirements which each security guard must read and have full knowledge and understanding of the contents. Galthung (2006) identified other aspects of planning of security operations to include: establishment of security guards headquarters and guards shelters usually located near main gate to serve as terminal for installation of Closed Circuit Television (CCTV); determine techniques and modalities for excursion of guards' duties and for easy detection of security lapses, identification of violators and writing comprehensive security reports; determine of guard's recruitment criteria so as to ensure the employment of security guards who are honest, intellectually alert, meticulous, open minded, articulate and resourceful; planning of training and re-training of security guards to ensure that they are able to perform their routine duties competently and to meet emergencies speedily and effectively.

\section{Methodology}

This study was focused on three selected tertiary educational institution in Kebbi State. These institutions include Adamu Augie College of Education Argungu, School of Nursing and Midwifery Birnin Kebbi and College of Agriculture Zuru. Descriptive survey was adopted for the study and the population of the study consistent of 13 management staff deliberately chosen from each school to include the Provost, Deputy Provost (Academic). Deputy Provost (Administration), the Registrar, the Bursar, the Chief Security Officer, the Estate Engineers, the Librarian, and five Deans of Schools. Because of the small number, all the security guards in the three institutions were taken as participants for this study. This gave a total of 150 participants for the study. Two self-designed and validated instrument 
tagged: "Role of Security Guards and Planning of Security Operations Questionnaire" (RSGPSOQ) and School Effectiveness Questionnaire (SEQ) with reliability index of point 0.76 snd 0.79 respectively were personally administered by the researcher with the help of trained research assistants. Mean scores, Standard deviation, Standard scores (z-scores) were used answer the research questions while Pearson correlation coefficient at 0.05 alpha level was used to test the hypothesis.

Although a total of 150 questionnaires were distributed, only 140 copies were eventually retrieved and all were found usable for data analysis. The key issues in the study were the ascertainment of the respondent's level of awareness of the roles of security guards and planning of security operations. Hence they were asked to indicate their level of awareness of each of the items listed on the instrument. The responses were scored on a five point Likert-type rating scale ranging from scale 5 for "high level of awareness" to 1 for "no awareness". The responses were subsequently summarized using standard deviation and standard scores and presented in tables.

\section{Results}

Two research questions were answered and one hypothesis was tested in this study.

Research Question 1: What is level of awareness of types of security operations in tertiary educational institution in Kebbi State?

This research question was answered and presented in table 1

Table 1: Awareness of Types of School Security Operations in Tertiary Institutions

\begin{tabular}{llccl}
\hline S/N & Roles & $\overline{\mathrm{X}}$ & $\mathrm{SD}$ & Z-Score \\
\hline 1 & Prevention of crimes, fire accidents & 3.72 & 1.07 & 3.20 \\
2 & Serving as body guards to principal officers & 2.64 & 1.10 & 2.55 \\
3 & Enforce safety rules and security regulations & 2.81 & 1.09 & 4.02 \\
4 & Joint security activities with other agencies & 2.79 & 1.01 & 3.92 \\
5 & Patrolling school premises for crime detection & 2.38 & 1.09 & 0.22 \\
6 & Controlling traffic, parking and trespass & 3.05 & 1.02 & 6.14 \\
7 & Documenting of visitors at School Gate & 2.42 & 1.22 & 0.65 \\
8 & Identification and authorizing access to visitors & 1.78 & 1.27 & -4.77 \\
9 & Searching entrants to school buildings & 2.14 & 1.26 & -1.85 \\
10 & Querying, suspected persons, vehicles and goods & 3.02 & 0.96 & 5.83 \\
11 & Conducting researches on security matters & 1.76 & 1.13 & 4.05 \\
12 & Dealing with loss and found items & 1.92 & 1.19 & -3.53 \\
13 & Reporting security breaches & 2.86 & 1.06 & 4.12 \\
14 & Arresting and restraining criminals & 2.19 & 1.17 & -1.16 \\
15 & Responding to emergencies & 1.57 & 1.31 & -6.63 \\
16 & Performance of first aid to victims & 1.38 & 1.27 & 8.27 \\
\hline & Mean & 2.34 & 0.12 & \\
\hline
\end{tabular}


Analysis of data in table 1 revealed high level of awareness (in decreasing order) of controlling traffic, parking and trespass $(\mathrm{z}$-score $=6.14)$; querying suspected persons, vehicles and goods $(\mathrm{z}$-scores $=5.83$ ); reporting security breaches $(z$-score $=4.42)$; enforcing safety rules and security regulations $(z$-score $=$ $3.92)$; preventing crimes, fire and accidents ( $\mathrm{z}$-score $=3.20)$; serving as body guard to principal officers (z-score $=2.25)$; documenting of visitors at schools gates scores $(z$-score $=0.65)$; good patrolling of school premises for crime detection $(z$-score $=0.22)$. Similarly, there was a relatively low level of awareness of their roles in the areas of: responding to emergencies $(\mathrm{z}$-score $=-1.16)$; searching quitrents to school buildings ( $\mathrm{z}$-score $=-1.85$ ) dealing with loss and found items (z-score $=-3.53$ ); identify and authorizing access to visitors $(\mathrm{z}$-score $=04.77)$; conducting research on security matters (z-score $=$ 6.63); and performance to first aid to victims ( $\mathrm{z}$-score $=-8.27$ ); further analysis recalled that majority of respondents $86(61.43 \%)$ have high level of awareness of their roles while (35 or 13.57\%) have low level of awareness of the roles in the perform of society operators. On the average the mean score of 2.34 and standard deviation of 0.12 indicate that there is low awareness of the various types of school security operations that are supposed to be carried out in tertiary institutions in Kebbi State.

Research Question 2: What is the quality of planning of security operations in tertiary educational institutions in Kebbi State?

This research question was answered and presented in table 2

Table 2: Respondents' Judgment on the Quality of Planning of Security Operations

\begin{tabular}{llllc}
\hline S/N & Quality of Planning & $\overline{\mathbf{X}}$ & SD & Z-Score \\
\hline 1 & There are well established Posts and Patrols & 2.87 & 1.02 & 10.44 \\
2 & Time requirements for Posts and Patrols well planned & 2.54 & 1.06 & 6.33 \\
3 & Patrol logistic are well planned & 1.97 & 1.26 & -0.87 \\
4 & Guard instruction are well prepared & 1.91 & 1.14 & -1.55 \\
5 & Guard manual is well prepared and circulated & 1.26 & 1.25 & -9.89 \\
6 & Guard headquarters and shelters are well planned & 2.43 & 1.21 & 4.88 \\
7 & Guard methods and techniques are well articulated & 2.68 & 1.23 & 8.09 \\
8 & Guard selection criteria is well established & -1.47 & 1.32 & -7.23 \\
9 & Guard training and re-training is well established & 1.59 & 1.19 & -5.74 \\
\hline & Mean & $\mathbf{2 . 0 8}$ & $\mathbf{1 . 1 8}$ & \\
\hline
\end{tabular}

From Table 2, analysis revealed high level of well-established posts and patrols (z-score $=10.44)$; general meeting and techniques well-articulated $(\mathrm{z}$-score $=8.09)$; time requirements for posts and patrols well planned ( $\mathrm{z}$-score $=6.33$ ); and general headquarters and sheets well planned $(\mathrm{z}$-score $=4.88)$. On the other hand, the responded perceived that there was poor planning of security operates in the areas of operation of general manual ( $\mathrm{z}$-score $=-9.89$ ); general selection criteria $(\mathrm{z}$-score $=-7.23$ ); general training and re- 
training ( $\mathrm{z}$-score $=-5.74)$, general instructions $(\mathrm{z}$-score $=-1.55)$; and patrol logistic $(\mathrm{z}$-score $=-0.87)$. Furthermore, the analysis equally revealed that $44 \%$ of the respondents to pervade that the quality of planning of security activities was high, $34 \%$ had moderate rating and $22 \%$ registered low rating for planning of security operates. As a whole the means score of 2.08 and standard deviation of 1.18 indicate that the quality of planning of security operations in tertiary educational institution in Kebbi State is poor

Hypothesis: Ho1: Awareness of security operations and quality of planning of security operations do not significantly co-relate with school effectiveness in tertiary educational institutions in Kebbi State.

The result of the correlation analysis is present is table 3 .

Table 3: Test of Statistic Independence among Security Variables and School Effectiveness

\begin{tabular}{cllll}
\hline S/N & School effectiveness variables & $\begin{array}{l}\text { Correlation } \\
\text { co-efficient }\end{array}$ & $\begin{array}{l}\text { Sig. } \\
\text { level }\end{array}$ & Comment \\
\hline 1 & Teaching, research and community service are done & -.091 & .086 & $\mathrm{~ns}$ \\
2 & School environment is alert to security challenges & -.136 & .014 & $\mathrm{~S}^{*}$ \\
3 & Staff and students feel well protected in your school & -.125 & .017 & $\mathrm{~S}^{* *}$ \\
4 & There is peaceful environment at all times in your school & -.173 & .001 & $\mathrm{~ns}$ \\
5 & There is minimum crime in your school & -.060 & .237 & $\mathrm{~ns}$ \\
6 & There are rapid response to emergency in your school & -.041 & .410 & $\mathrm{~ns}$ \\
7 & There is cooperation with other security agencies & -.031 & .630 & $\mathrm{~ns}$ \\
8 & There is enforcement of safety rules and regulations & -.06 & .282 & $\mathrm{~ns}$ \\
9 & Nobody is above the law in your school & -.12 & -.017 & $\mathrm{~S}^{*}$ \\
\hline
\end{tabular}

$\mathrm{n}=140$

Source: Filed Survey, 2019

$\mathrm{S}^{*}=$ Significant a $\mathrm{p}<.05$

$\mathrm{S} * *=$ Significant at $\mathrm{p}<. .01$

$\mathrm{ns}=$ not significant at $\mathrm{p}<.05$

The above result show that each of items: nobody is above the law (-.12); there is minimum crime in school (-.060); there is rapid response to emergencies (-.041); there is cooperation with other security agencies (-.031); and there is enforcement of safety rules and regulations have signify relationship with awareness of security rule by security guards and planning of security planning.

However, a significant relationship was found to exist between each of 1) school environment alert to security challenges, (-.136); staff and students feel well defended (-.125); there is peaceful environment at all time (-.173); lives and properties are well protected and security awareness and quality of security operation in tertiary educational institutions in Kebbi State. 


\section{Summary of Major Findings}

The following findings were made in this study:

1. There was low level of the types of security operations in tertiary institutions in Kebbi State, Nigeria

2. There is poor quality of planning of security operations in tertiary institution in Kebbi State.

3. There was a co-relation among awareness, planning and school effectiveness variables in tertiary educational institutions in Kebbi State.

\section{Discussion of Findings}

Result ion table 2 show that security guard have a high level of awareness in the area of traffic control especially at gate duty when they stop and check visitors. They report safety regulation and participate in joint security activities with other security agencies, such as Civil Defense, Police and Vigilante groups. This is because they perform routine duties on daily basis. However their level of awareness of their roles is very low or poor when it comes to responding to emerging especially when there is a natural disaster, accident, sudden attack or fire outbreak. They are also generally unaware of their role in conducting research, as well as providing First Aid to victims of accidents and other calamities. Although, a small percentage of $13.57 \%$ acknowledged their ignorance of their security rules as guards, they are probably more correct and truthful than the majority considering the poor quality of security services rendered in schools. It also implies that people's awareness of their roles may not be a guarantee for effective for performance due to extraneous variables. It express the common trend in the Nigeria society where people may know what is right thing to do but still continue to do the wrong thing that favours them (Sani, 2007).

Table 2 shows that majority of participants either rated the planning of security operations moderately (34\%), or very low (22\%) which means that the majority $(56 \%)$ were of the view that a lot needs to be done on imprint the quality of planning of security operation of guard manual which is virtually nonexistent in the schools, inadequate plans for training of security guards, giving of instruction as well as in planning for patrol logistics. They tend to confirm the poor planning of security in schools as observed any Zakariya (2006) and Paleru (2008).

Table 3 demonstrated that there was generally little or correct between the security variables of awareness of guards roles, planning of security operations and school effectiveness in tertiary educational institution in Kebbi state. It implies that the relative security enjoyed in the school which is taken as the indicator of school effectiveness in not necessary the outcome of security efforts of the schools but a spill 
over of the overall peace enjoyed by the state. This means that if the tertiary schools are suddenly confronted with series security challenges they are likely to be vulnerable and helpless (Manga, 2015).

\section{Conclusion}

Based on the findings of this states, the following conclusions are drawn

1. The level of awareness of expected security roles by security guard is generally low

2. The quality of planning of security operations is generally low.

3. The level of awareness of awareness of role performance by security guards as well as planning of security operating are generally low to significantly affect school effectiveness in terms of providing a secured environment for teaching research and community service.

\section{Recommendations}

Based on the findings, conclusions and implies of this study, the following recommendations are hereby provided:

1. School managers should focus their attention on improving the awareness of the security guards employed in the schools, towards a better understanding and appreciation of their roles. This could be done through on-the-job training, mentoring and in-service training. Opportunities should be provided for regular workshops, symposiums, seminars, conferences and other approaches to enlighten security guards in the performance of the roles.

2. There should be more scientific planning of security operations so as to ensure that all critical variables of logistics, communications, supervisions and motivation are taken into consideration, for effective service delivery and school effectiveness.

\section{Implications to Educational Management}

Educational managers in tertiary educational institutions in Kebbi State need to recognize that there are many security guards in their schools who are not properly enlightened on the roles that they are expected to play in the discharge of their obligations. There is also the need to objectively recognize the fact that the quality of planning of security operators is not satisfactory. This implies that school managers must take up the challenge of improving the role awareness of security guards and ensuring better planning of security operations in their schools.

\section{References}

Abolurin, A. (2010). Security and its management in Nigeria: Achievement and challenges of the Nigeria Security and Civil Defense Corps. Ibadan: John Archers Publishers Ltd. 
Adelugba, D. \& Ujomo, P.O. (2008). Rethinking security in Nigeria: Conceptual issues in the quest for social order and national integration. Dakar: CODESRIA, 172p

Agbu, C.; Adamu, S.M. \& Wamu, A. (2014). Protecting our schools, Leadership Weekend. Saturday, July 5, 2014. P.3. online: www.leadership.ng

Akangbou, S.D. (2015). Introduction to economics of educational planning in Nigeria. New Delhi: Vicas Publishing Company Pvt. Ltd.

Akinwumi, F.S \& Adebayo, T.A (2013). Insecurity as a challenge to educational development in Nigeria. In Ayeni, A.O, Emetrom, U.G; Abdulkareem, A.Y, Undie, J.A and Okon, J.E (Eds). Managing Education for National Security. NEAP Publication. Ibadan. His Lineage Publishing House.

Akosun, M (2013). Functional education as panacea to insecurity in Nigeria. In Ayeni A.O, Emetrom, U.G; Abdulkareem, A.Y, Undie, J.A and Okon, J.E (Eds). Managing Education for National Security. NEAP Publication Ibadan. His Lineage Publishing House.

Alabi, A.O (2011). Educational Reform. A Bedrock for National Development. Keynote Address at $2^{\text {nd }}$ Conference, College of Education Oro, Kwara State, Nigeria.

Arisi, R.O. (2011). Social studies education of a panacea for national security in Nigeria. African Research Review 5(2)19. An International Multi-Discipline Journal, Ethopia.

Dasuki, S. (2013). Nigeria security challenges. The way forward. $3^{\text {rd }}$ Seminar held at the National Private College, Abuja: Alumni.

Galthung, J. (2006). Violence peace and research. Journal of peace research 3(1) 167-191.

Manga, S.D. (2014). School plant security. Unpublished manuscript. Usmanu Danfodiyo University, Sokoto Nigeria.

Manga, S.D. (2015). Safety And Security Consideration In The Construction Of School Plant In West Africa. International conference paper presented at university of Abomey, Cotonou, Benin Republic, may 2015.

Mclaren, p. (2018). Life in school. New York: Longman

Paleri, R. (2008). National Security: imperatives and challenges. New Delhi: Tata McGraw Hill

Suleiman, T.M (2018). Principles of security guarding. Zaria: Ahamdu Bello University, Press Ltd. Nigeria.

Ufaha, R. \& Odunze, C. (2015). Safe school initiative: an appraisal. Diamond education magazine page $10-15$.

Zakariya, F. (2010). Youth conflicts security and development. Online: www.realityofaid.Org.

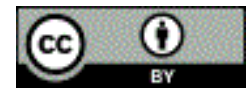

This work is licensed under a Creative Commons Attribution 4.0 International License. 